\title{
GENRE APPROACH IN CREATIVE WRITING PEDAGOGY IN ENGLISH IN UPPER PRIMARY CLASSES IN KENYA
}

\author{
Sophie Ahono Maninji \\ Phd Research Student, \\ Department of Educational Communication, \\ Technology \& Curriculum Studies, \\ Maseno University, \\ Maseno, Kenya.
}

Article DOI URL : $\underline{\text { https://doi.org/10.36713/epra6595 }}$

DOI NO: 10.36713/epra6595

\begin{abstract}
Writing can be used to measure learning of the other three language skills and written materials be used for reference in future. Creative writing $(C W)$ is the production of texts which have an aesthetic rather than a purely informative, instrumental or pragmatic purpose. It is a personal writing where the purpose is to express thoughts, feeling and emotions in an imaginative, unique, and sometimes poetic way. Of all the four language skills, creative writing is a high order skill that calls for molding through appropriate pedagogical approaches. In Kenya, English is both an examinable subject and a language of instruction. CW accounts for $40 \%$ of the total score in English subject. However, over $62 \%$ of learners fail to achieve writing competence at the end of primary course. Primary schools in Vihiga County have persistently underperformed in $\mathrm{CW}$ with more than (70\%) of Class 8 learners scoring below the average mean mark. Despite this underperformance, only a few studies on $\mathrm{CW}$ pedagogy are available. $\mathrm{CW}$ studies conducted in Kenya have established that $60 \%$ of teachers find it difficult to teach $\mathrm{CW}$ while $75 \%$ of learners find it boring. These have implications for pedagogy and students' writing enthusiasm. The objective of this study was to explore the use genre pedagogic approach and its effectiveness in the development of $\mathrm{CW}$ skills. Archer's theory of reflexivity which views writing as internal and external conversations was used. The study used qualitative exploratory research design and the study was conducted in Vihiga County. The data collection tools were Lesson Observation Schedule and Interview Schedule whose validity and reliability were tested through triangulation. From Class 6-8, 30 lessons in 10 purposively selected schools were observed and 30 teachers whose lessons had been observed were interviewed. Data were analyzed thematically through transcription, coding and identification of themes. The key finding was: inappropriate use of genre approach due to teachers' knowledge gaps on CW pedagogical approaches. The study recommended that teachers of English use genre approaches appropriately in CW pedagogy and the Ministry of Education to in-service teachers of English on CW approaches. The results are useful to teachers of English and Teacher Training Institutions.
\end{abstract}

KEY WORDS: Approaches, Genre Approach Creative Writing and Upper Primary Learners.

\section{INTRODUCTION}

All human beings desire a sense of ownership when it comes to their creative work and writing can be one of the most deeply satisfying acts as it gives the author the opportunity to exhibit such ownership (Anastasiia \& Mishchenkob, 2016). It also provides the author with an outlet for creativity and personal expression - a chance to learn about who he or she is as an individual (Urquhart, 2005). There are two broad categories of writing: creative writing and functional writing. CW involves dialogues, conversations, plays, poetry anecdotes and stories while functional writing includes: reports, book reviews, scientific experiments, articles, letters, announcements, speeches, notes and notices among others. $\mathrm{CW}$ is highly imaginative while functional writing is factual (Gathumbi, 2008: 59). CW helps the writer achieve the aforementioned. Writing can be described as an activity that is both exciting as 
well as enriching (Martin, 2001). However, this excitement and enrichment depends on its pedagogy. In upper primary classrooms in Kenya, CW typically refers to imaginative composition writing, which was the focus of the present study. In Kenya, one of the objectives of the primary English curriculum is for all pupils to acquire sufficient command of English in spoken and written forms to enable them to communicate fluently, independently and accurately in everyday life. Pupils are also expected to acquire writing skills to express own ideas meaningfully and legibly in English (KIE, 2002; 2004). Upper primary school learners are exposed to both functional and $\mathrm{CW}$. However, much emphasis is on $\mathrm{CW}$ which is evaluated formatively and summatively. Of all the items under writing, as observed by Njuguna (2012), CW in primary schools in Kenya receives much emphasis compared to other English language skills because it is the only way of evaluating written competence in learners at the end of the primary course. Learners are expected to write a composition which carries $40 \%$ of the total English Kenya Certificate of Primary Education (KCPE) score. The other three skills of language; listening, speaking and reading, share the remaining $60 \%$ of the total KCPE score. The learners are expected to creatively express themselves using their imagination and figurative language. Although such importance is attached to $\mathrm{CW}$, it has remained challenging to upper primary learners over years. Gitogo (2013), commenting on Kenya Certificate of Primary Education (KCPE) English composition themes says that English composition is one of the areas that give KCPE candidates, parents and teachers sleepless nights because it is considered challenging and at the same time a key determinant of the final grade a learner will attain in English subject; which determines their transition from primary to secondary schools. According to Schoonen, R., Van Gelderen, A., Stoel, R., Hulstijn, J., De Glopper, K. (2011), the complexity of $\mathrm{CW}$ is in its nature, that is, it demands a grammatically, lexically and syntactically correct and well organized composition, and this task is even more complex and demanding when writing is in another language different from the native or mother tongue as in the case of the Kenyan learners. Consequently, Cheung, (2016), and Gathumbi, Ssebunga and Masembe (2008) postulate that learners do not achieve high degree of correctness in continuous writing (compositions) because in a second language situation, writing skills are the most difficult to master and learners have a great difficulty in understanding what is required in continuous writing in English. There are many activities that should be done at the same time during writing thus making writing complex and difficult. While expressing ideas, students need to think about the appropriate vocabulary, the spelling of the words, the mechanics, the style, as well as the correct structure to be used in arranging good English sentences. These activities have to be done effectively because in writing we do not get an audience and immediate feedback hence we have to get it right the first time (Hadfield, 2008). Besides the nature and complexity of CW skills, L2 learners' problem in CW skills can be caused by several factors: the curriculum, the approach used by teachers in writing instruction, and the teachers' lack of ability in writing instruction (Eliwarti and Maroof, 2014). The present study focuses on the approach because Ochako (2019) argues that the instructional approaches are important variables in effective teaching to enhance learning of imaginative writing. Approaches to $\mathrm{CW}$ pedagogy are unique in shaping certain aspects of CW like accuracy, fluency and creativity (Ibrahim, 2013). This paper examines the genre approach in teaching $\mathrm{CW}$ in upper primary classes because Paltridge (2004) explains that genre approach to teaching writing focuses on teaching particular genres such as stories, essays, assignments, and other pieces of writing that students need to be able to produce in academic settings. In regard to assignments and academic settings, in Kenya, CW is examined and caters for $40 \%$ of the learners' final score thus making it relevant and worth of investigation. Most importantly, regardless of some composition scholars (Lin, 2006; Johns, 2008; Hasan \& Akhand, 2010; Andrew \& Romova, 2012) claiming a wide applicability of genre-based approaches in various educational settings, there are still significantly limited studies (if any) conducted to empirically investigate the application of the genre-based approach in L2 CW classrooms. In the genre approach, there is a different way of looking at writing. This therefore informed the premise of looking into this approach in order to inform $\mathrm{CW}$ classroom practices in Kenya.

\section{The Genre Approach}

According to Martin et al (2003), genre is "a staged, goal-oriented social process" (p. 7). It is "Social" because people take part in genres with other people; just as learners have to write creatively with an audience in mind, "goal-oriented" as genres are used to have things done; that is communicating to your audience in a new, pleasant and interesting way, "staged" since it consumes a few steps to achieve the goals wanted thus it can be accomplished in a few minutes as opposed to the process approach. Thoreau (2006) postulates that genre writing is a kind or type of writing in which it has a typical style, particular target of readers, and a specific purpose. Considering Thoreau's statement, it can be argued that genre covers three main aspects namely: writing style, readers, and goal (goal oriented). In line with style, Thoreau, then claims that writing style means how something is 
written; the words that are used and the way the information is organized; all of which are key ingredients to effective $\mathrm{CW}$.

The proponents of genre approach to teaching writing like Kay and Dudley-Evans (1998) have argued that it is more effective for learners to advance their writing skills in second language since it helps free students from their severe worries over writing. For a learner to imagine and compose an interesting piece of writing, they need to be free from any worry to enhance the flow of creative thoughts. Another important aspect of this view is the one that sees language as occurring in particular cultural and social contexts, and thus, cannot be understood outside its context (Kim \& Kim, 2005; Ibrahim, 2013). This is an important aspect in $\mathrm{CW}$ since the learner is expected to compose a story with characters behaving in a certain social, cultural, political or economical environment way as dictated by the title or the input statement given. It can therefore be concluded that genre writing is a new perspective to teaching writing due to its different perspectives.

A notable thing about genre approach is fact that writing is embedded in social situation, so that a piece of writing is meant to achieve a particular purpose which comes out of a particular situation. In terms of genre writing, Hyland (2003) as cited in (Dirgeyasa, 2015) proclaims that: Genre implies that students to write not just to write but to write something to achieve some purposes such as it is a way of getting something done, to get things done, to tell story, to request an overdraft, to describe a technical process, to report past event, and so on, we follow certain social convention for organizing messages because we want our readers to recognize our purpose. This postulation captures the essence of CW in Kenya which is to enable learners to write a continuous prose of narrative, a simple letter, a short dialogue and a few other types of prose that are accurate, fluent, relevant and imaginatively original. Firkins, Forey, and Sengupta (2007) elaborate in detail the genre as a model of teaching and learning. They claim it is cyclic. They also propose three stages which must be followed and implemented during the teaching and learning process. The three stages are:

a. Modeling a text,

b. Joint construction of a text, and

c. Independent construction of a text.

In modeling a text, there are four practical steps which must be implemented during the teaching and learning process. The four practical steps are:

a) The teacher chooses a certain type of genre writing in order to develop the classroom activities. In this case, type of genre must match with the students needs and market needs where they will work later on.

b) The teacher and the students discuss the text genre by modeling and deconstruction or even manipulating the text. c) The students are directed and situated in order to know and understand the function of the text, the communicative purpose of the text. Take for example the genre procedure writing-the function of procedure and the purpose of writing procedure.

d) The students then, study the vocabulary usages of a certain genre procedure, grammatical or structural patterns of procedure, and then the students practice the procedure if necessary.

In joint construction stage, the students start to do something more practical and operational dealing with writing. However, their work of genre writing is not writing at all because they modify and manipulate the text given. The students are still guided and helped by the teacher before they become really independent writer of a certain genre taught and learned. As a matter of fact, there are three practical steps on how joint construction stage is developed and implemented:

a) The students reconstruct the certain genre writing given. In this case, the student may revise and paraphrase the vocabulary usage, the grammatical patterns, and textual devices if necessary by their own words.

b) The teacher continuously guides the students to discuss and order the students to remember so that they really understand well about the genre type given.

c) Before going forward to stage three, the independent construction of a text. Stage modeling text and joint construction are important to review.

Under Independent construction of a text, after having prior understanding and experiences of stage one and stage two, the students are ordered to write a certain type of genre as what they have learned before. The student write a given genre type independently. In this case, the teacher must be sure that the students really understand the features of a certain genre such as the communicative purpose, structure element of the text, grammatical patterns usage, relevant vocabulary usage, and textual devices as well.

When the above model is effectively adhered to, Genre approach exhibits several advantages as Morgan (2007) pointed out how rhetorical instruction plays a pivotal role in writing improvement as prior knowledge. In this context, the genre approach is very beneficial because it brings together formal and functional properties of a language in writing instruction, and it acknowledges that there are strong associations between them using a sample model which learners can imitate. As Bhatia (1993, as cited in Kim \& Kim, 2005) recommended, it is meaningful for writing instructors to tie the formal and functional properties of a language together in order to facilitate students' recognition of how and why linguistic conventions are employed for particular rhetorical 
effects (p. 6). Therefore, an assigned genre seems to serve as an influential tool for both the learning and teaching of writing [for both students and teachers]. In addition, the genre approach encourages students to participate in the world around them (Kim \& Kim, 2005), to comprehend writing as a tool that they can utilize, and to realize how writers manage content to promote logical organization. It also allows students to become more flexible in their thinking and eventually to realize how authors organize their writings Hyland (2003). Furthermore, some proponents have indicated that the genre approach is more suitable for learners at beginning or intermediate levels of proficiency in a second language rather than those at advanced levels, in that it releases students from deep anxieties about their writing tasks. The foregoing assertion makes it an appropriate approach for upper primary classes.

\section{The Aim of Creative Writing}

Writing teaches learners' critical thinking and organizational skills that they carry over to every other subject. Writing can also be described as a communicational vehicle, an assessment tool, and an intellectual exercise that benefits both the teacher and the student. Teaching of creative writing is a way of development of communicative competence. It is a special type of the composition which assumes a nonstandard thinking of the author. Writing is a powerful tool for thinking and learning -so powerful that it should not be limited to the writing workshop. Students must have opportunities throughout the day to engage in writing. Improving writing is not the major purpose for incorporating writing in various curriculum areas. Learning of $\mathrm{CW}$ has a special place in education as a whole because it equips learners with the basic skills of language and gives them opportunities for free expression of feelings and experiences (Khan, 2011). Learning of imaginative writing starts from the classroom environment through teaching using various strategies and learners' practices (Ochako, 2019). Learners are expected to creatively express themselves using their imagination and figurative language (Mwangi, 2016). However, learners underperform in $\mathrm{CW}$ because they face great difficulty in expressing themselves in simple English during CW (Kalemesi, 2016). The aim of teaching $\mathrm{CW}$ is to make the students be able to express themselves in different literary forms (Neupane, 2014). Apart from sharpening students' ability to express their thoughts clearly, CW encourages them to think beyond the ordinary and use their imagination to express their ideas in their own way (ORELT, 2015). For instance, if one plans to pursue a career in journalism that deviates its style of writing from news reporting like an opinion columnist, a composer of editorials, or something within that nature, one needs to have skills of $\mathrm{CW}$ well presented because of its appealing nature (Desiree, 2014). CW also promotes one's ability to communicate (Northway, 2011), besides developing critical thinking skills and ability to evaluate a piece of literary work among students. As a result, it improves students' problemsolving abilities (ORELT, 2015). In addition, creative writing gives out information, makes learning more interesting and helps one to be a better writer through practice (Kwok, 2015). Writing is very important as a tool for measuring the learning outcomes of imaginative writing. This implies that one's ability to be creative can be clearly seen through written imaginative texts after learning imaginative writing. In this case, the teacher is fundamental in enhancing learning of imaginative writing through the approaches employed.

\section{RESEARCH METHODOLOGY}

The objective of the present study was fulfilled through a qualitative exploratory research design which, according to Burns and Groove (2001), is conducted to gain new insights, discover new ideas, and for increasing knowledge of the phenomenon. The study explored the Genre approach upper primary teachers employ during their writing lessons in order to gain insights into the effectiveness of this approach in imaginative composition writing instruction and suggested ways of improving the same in Vihiga County primary schools. The study was carried out in Vihiga County in the Western Region of Kenya. The choice of Vihiga County was influenced by the fact that the public primary schools in this area have persistently underperformed in English composition and also its rural setup that can exemplify practice as opposed to the urban setups which are well resourced and are deemed to have L2 competent learners. Stratified purposive sampling was employed to select teachers of English from the purposively selected schools from class 6,7 and 8 for lesson observation during their teaching of $\mathrm{CW}$. Teachers whose lessons had been observed were interviewed by the researcher in order to help the researcher corroborate the data that had been collected. Stratified purposive technique was appropriate for the present study because it focuses on characteristics of particular subgroups of interest. The sample was stratified based on the level of upper primary classes hence the Class 6,7 and 8 that were involved in the study.

All the 30 teachers of English from the 10 purposively selected schools were interviewed and 30 imaginative composition lessons; one from each class in the 10 selected schools was observed during instruction. The 30 teachers interviewed and the 30 lessons observed were informed by Guest, Bunce, and Johnson (2006) who advocate for saturation, the point 
at which a researcher no longer receives any new information or insight into the phenomenon of study from each subsequent interview or observation, and it often occurs at around 12 for a homogeneous participant group. They further argue that a minimum of 15 for most qualitative interview studies works very well when the participants are homogeneous. In this study, homogeneity of participants involved teachers of English in upper primary classes for interview and observation of upper primary $\mathrm{CW}$ lessons. For a particular group, saturation often occurs between 12 and 15. However, Nastasi (2005) recommends a sample size of 30 for in-depth interview thus the interviewing of the 30 teachers of English in upper primary classes. Oral semi structured interview schedules were administered to class 6, 7 and 8 teachers of English on the genre approach and its effectiveness in developing $\mathrm{CW}$ skills because interview schedules are a feasible and adaptable way of finding out information (Cresswell, 2009). For classroom observation, according to Wragg (2011), they are used in a study and should suit its purposes. Therefore, the classroom observation methods and procedures were carried out in line with the research's main purpose of establishing how effective the Genre approach in CW pedagogy was and current composition writing practice in Kenyan upper primary classrooms.

Stake (2005) explains that to give quality, credibility, and trustworthiness to a qualitative research, certain methods are used which include: triangulation, saturation, member checking and selfdisclosure (Reflexivity). In qualitative research, validity entails the researcher checking for the accuracy of the findings by employing certain procedures, while reliability indicates that the researcher's approach is consistent (Creswell, 2009). To ensure that the findings in this research are accurate and credible, a number of measures were taken. Validity strategies such as data triangulation and the use of thick and rich descriptions of the procedures and findings were used. By converging data from the two sources, conclusions were drawn from various angles making the research findings trustworthy. Secondly, the researcher involved peers and experienced researchers in reviewing key concepts, methodology and analysis and to help check the credibility of the research rationale, research process and report as suggested in research literature (Stake, 2006).

Regarding reliability, Richards (2009) explains that "dependability in qualitative research involves an interrogation of the context and the methods used to derive the data" (p159). Yin (2003) suggests that one way of enhancing dependability is to make clear and detailed descriptions of the steps followed in the study. To ensure dependability in this study, care was taken to make a thick description of the entire research process in a manner that makes it possible to carry out a similar study in another context, if necessary (Ponterotto, 2006). In the process of data generation, the researcher accumulated a data set consisting of interview and observation notes. The researcher utilized thematic analysis. Braun and Clarke (2006) explain that: Thematic analysis is a method for identifying, analysing, and reporting patterns (themes) within data. It minimally organizes and describes your data set in (rich) detail. To ensure consistency in approach during the study, the exploratory study procedures was documented and applied consistently in the data collection phase by immediately describing in detail the opinions and feelings and the behavior captured during interviews and classroom interactions; then transcribing the data. The same procedure was used for all the ten classroom observations. Once classroom observation data was transcribed from recorded classroom interactions and checked for accuracy to make sure that it does not contain mistakes. Measures were also taken in thematically coding to ensure that there were no drifts in the definitions of codes or shifts in the meaning of codes during the process of coding.

Data analysis was achieved using content and thematic analysis and discourse analysis. Interview data was subjected to narrative while classroom observation data was analysed using discourse analysis. Teacherlearner interactions from the classroom observation were used to corroborate the data from the interviews with teachers about the methods they employ to teach CW. Narrative approach was used to present data from teacher interviews. In terms of ethics, according to Mason (2002), the researcher observed truthfulness and all participants were given accurate and detailed information about the research, their express consent, confidentiality and anonymity were assured, any sort of harm was avoided and the researcher show appreciation of the participants' support in any appropriate manner (Cohen et al., 2007). The researcher then wrote a detailed report using qualitative data that was thematically interpreted and described in subsection under the genre approach in focus.

\section{RESULTS AND DISCUSSIONS}

The approach was utilized in Class 7 and 8 lessons only. Class 6 teachers did not use this approach although the class was part of the study. They mainly utilized product approach followed by process approach. Genre approach is considered to be new and it has strong similarities with product approach (Harmer 2007) and, in some ways, genre approach can be regarded as an extension of product approach (Badger and White 2000). Badger and White (2000) argues that the use of model texts and the idea of analysis imply that learning is partly imitation and 
consciously applying rules. Thus, genre-based approaches see writing as essentially concerned with knowledge of language, and being tied closely to a social purpose, while the development of writing is largely viewed as the analysis and imitation of input in the form of texts provided by the teacher. The genre approach has three phases: modeling the target genre, where learners are exposed to examples of the genre they have to produce; the construction of a text by learners and teacher; and, finally the independent construction of texts by learners (Eliwartil \& Maarof; 2014). The following are Class 7 and 8 Genre approach sample lessons. The following notations were used in the transcript of the lesson extract;

$\begin{array}{ll}P: & \text { Pupil } \\ T: & \text { Teacher } \\ C L: & \text { Chorus response from the learner } \\ (.): & \text { Silence (for } 4 \text { seconds) } \\ (-): & \text { Prolonged silence (for } 10 \text { seconds) } \\ \text { NR: } & \text { No response }\end{array}$

\section{Sample 1: Genre Oriented Approach Class 7 Lesson Development Episode}

T: $\quad$ We have different types of compositions as we have said (.) Examples are letters and narratives (.) Do you love stories? They form the basis of our topic today. Ok?

CL: $\quad Y e s$

T: $\quad$ So, who can tell us a short story? (-) (NR). Ok, stories fall under imaginative compositions (.) In imaginative compositions think about something which may or may not be true. That's why they are called imaginative. Ok?

CL: $\quad Y e s$

T: $\quad$ Mostly the story is started for you and you have to finish (.) Which one do you like, the starting or ending one?

CL: (mixed reactions from the learners. Some shouts the starting one while others are shouting the ending one.)

T: $\quad$ For example, complete the following story, "I will always be grateful to my sister for her act of bravery...when you have such, identify key words. Can we identify them (-)

L1: Grateful

T: Good, any other?

L2: $\quad$ Bravery

T: $\quad$ Yes(.)(name)

L3: Act.

T: $\quad$ Yes. Let's listen to the story and see what was expected of us. (The teacher reads the story at a moderate pace. Some learners lose concentration along the way probably due to the length of the story and the teacher's monotone.). Have we understood the story? What is the main thing in the story?

L4: $\quad$ The person in the story is happy because the sister risked her life to get him out of danger.

T: $\quad$ Good. Clap for her (Learners clap). Can we give two examples of such which we can Write about.

L4: $\quad$ A house burning while inside and your sister breaks the door to save you from burning.

T: $\quad$ Good. A second example? (-)(name)

L5: $\quad$ (.) Robbery (-). Thieves came to your house and your sister knocked one of them and you ran away.

T: $\quad$ When writing a story, you must make it interesting. How do we do that?

L1: Use phrasal verbs.

T: $\quad$ Good (.) Example of phrasal verbs?

(.)

L2: Pass out: Very good. Clap for her (learners clap). Any other? (name)

L2: Use proverbs

T: $\quad$ Something else?

L3: Exclamations.

T. Good.

\section{CONCLUSIONS}

T: $\quad$ Yes. Conclude by giving a moral lesson learnt. Okay, copy this composition in your books and finish it.

In Genre approach, students are expected to make decisions about genre and choice of topics and collaborate as they write. In the above extract, the teacher read a good model story which he could have used to discuss with the learners the rubrics of composition writing guided by the three steps in the model, that is, modeling the target genre, where learners are exposed to examples of the genre they have to produce; the construction of a text by learners and teacher; and, finally the independent construction of texts by learners. However, learners were only exposed to modeling of the target genre through the sample composition the teacher read in class. The last two phases; the construction of a text by learners and teacher and the independent construction of texts by learners were missing. Moreover, a major impediment to the development of CW skills in the lesson was a mention of the items and partial development of the items under investigation without clear demonstration to learners who are yet to develop their CW skills. Thoreau (2006) postulates that genre writing is a kind or type of writing in which it has a typical style, particular target of readers, and a specific purpose. Therefore, in terms of creativity, the genre approach is best suited to develop the skill as it can systematically 
guide learners on how to infuse conflict, unusual but appropriate use of words and language phrases and figured of speech, correct language structure, sentence formation patterns, creative use of language to create interest and capture the reader's attention and writing within the given topic (relevance) as expected by the Kenya National Examination Council. This is achieved because the learner can be guided on the appropriate style to make their $\mathrm{CW}$ unique and captivating because they know their target audience and the purpose of $\mathrm{CW}$. Another paramount aspect and a scoring point of $\mathrm{CW}$ is creativity which entails, unusual but appropriate use of words, phrases and figures of speech, language structure, sentence formation patterns, creative use of language to create interest and capture reader's attention and relevance (KNEC; 2015).Creativity can be well molded using the genre approach unlike the process and product approaches which develop accuracy and fluency respectively. In foreign or second-language writing, a genre-based approach refers to teaching learners how to make use of language patterns to achieve a coherent, purposeful composition (Hyland, 2003). The genre approach focuses on models and key features of texts written for a particular purpose. Christie and Derewianka (2008) define genre as 'social processes for achieving purposes within the culture'. In a $\mathrm{CW}$ class, it will entail classroom interactions that give rise to an interesting and unique text expressing the learners' originality and individuality as dictated by CW. Although the teacher attempted to infuse creativity in the lesson by asking learners how they can make their CW interesting, they items fronted by learners such as using phrasal verbs, proverbs and exclamations were not developed through the guidance of the teacher as prescribed by the Genre Approach model. This failure to guide learners on how to infuse and develop creativity in their written pieces impacts negatively learners CW.

Rose and Martin (2012) and Knapp and Watkins (2005) postulate that genre is a 'staged goaloriented social processes'. Martin and Rose point out that the fundamental definition of genre is that of configurations of meanings realized through language and modality of communication. The genre approach to writing supports students' writing with generalized, systematic guiding principles about how to produce meaningful passages for example in private stories. Cowley (2004) believes by approaching CW via genre, students' interest and motivation can be enhanced thus changing the notion of about $70 \%$ of learners who view $\mathrm{CW}$ as boring. So, it is appropriate to employ genre approach in Kenyan upper primary classroom, because a genre approach views how language is used for the particular purpose in the particular context. The learner should have knowledge of genre to understand the purposes, conventions and strategies to write imaginative composition successfully in different ways because by approaching $\mathrm{CW}$ via genre, their interest and motivation can be enhanced (Cowley, 2004, p. 79).

More so, genre approach requires samples of a specific genre to be introduced, and some distinctive characteristics of the given genre be pointed out so that learners notice specific configurations of that genre thus making it resemble the product approach in that a model text is analyzed on the basis of grammatical and text features. This is followed by guided writing in a joint construction stage before a final, free-writing stage (Badger \& White, 2000). The guided writing grounds the learner in the $\mathrm{CW}$ tenets being tackles as opposed to product approach where the learners have to imitate the model. Next, students attempt to produce the first draft through imitating the given genre hence making learners less apprehensive during composition writing. Looking at the Class 7 genre approach lesson, it falls short of these expectations. The teacher introduced a sample composition but failed to analyze it on the basis of grammatical and textual features, no guided writing was witnessed and the students did not have a free- writing session as expected. Therefore, the approach was not effectively utilized to develop CW competence in Class 7.

The application of genre approach in teaching has been criticized for stifling creativity by imposing models on students (Hyland, 2008), but, Hyland further clarifies that the genre does not dictate that the students neither write in a certain way nor determine what to write, it enables choices to be made to create meaning. This argument allows the teacher to manipulate classroom interactions and teach learners how to write creatively but the students are automatically guided very much to imitate since they are only provided with very little practice on developing linguistic skills. In accordance with this, Badger and White (2000) argue that the negative side of genre approaches is that they undervalue the skills needed to produce a text and see learners as largely passive; this passivity was pronounced in the lessons observed but it is a limitation that process approach to writing takes care of when effectively. Besides the use of a model, another aspect of genre approach displayed in the lesson was the mention of tenets that make CW interesting. This aimed at tackling the peculiarity of CW from other pieces of writing; a major aspect of genre approach. Just like the preceding approaches, genre approach was not effectively utilized since the teachers only mentioned the aspects of the approach without proper guidance to the learner. 
Sample 2: Genre Oriented Approach Class 8 Lesson Development Episode

$T$ :What do we consider when writing a composition? L1: Hand writing

T:Good (clap for him) (.) (name)

L2: Title

T:Good. Any other?(.)

\section{L3: Correct punctuation}

T: Good. Use speech marks when writing direct speech (no further instructions) (-) (name)

L4: Tenses.

T: $\quad$ Good. Now, remember to avoid silly mistakes. How do we avoid them? (-) (NR). Okay, by proof reading your work.

Another important point is flavouring our composition. How do we do that? (-)(name)

L5: Use expressions, for example, to express sadness or joy.

T: $\quad$ Good. These idiomatic expressions use them sparingly and for similes, at this level, use advanced ones (no examples given). Any other? (NR)

Okay, you can also use proverbs, metaphors and hyperbole (.)

Paragraphing is also very important. Just use indented paragraphing (.) Let us continue, I have an example of a KCPE question for 2008. "When we arrived at school at three o'clock from educational tour, we were surprised to find others on parade.

T: $\quad$ What are you to do in this case?

L1: $\quad$ Think of what could have caused the pupils to be on parade the unusual time.

T: $\quad$ Yes, very good. Some of such scenarios could be probably a sudden death of a teacher. Anything else? (.) (name)

\section{L: $\quad$ A visit by very important people.}

\section{CONCLUSION}

T: How do we finish our story?

L1: Finish with a proverb.

T: $\quad$ Yes a relevant one.

L2: Give a lesson learnt.

T: $\quad$ Good, any other?

L2: Use a rhetorical question.

T: $\quad$ Any question? (NR) Okay, copy this sample composition in your exercise books. Your composition should always be two pages and always use correct paragraphing.

In the Class 8 genre approach sample, the teacher's development began with asking learners what to consider when writing a composition. The learners stated good hand writing, correct punctuation, tenses and use of speech marks. These are aspects of accuracy which is one of the scoring areas of compositions in Kenyan primary schools but fluency and creativity was left out; items which could be molded through proper utilization of the process and genre approaches. To enhance accuracy, the teacher asked learners to avoid silly mistakes. She wanted to know what the silly mistakes were but she got no response from the learners and moved on without guiding the learners. This silence could imply lack of knowledge about the mistakes or boredom on the part of the leaner contrary to Hyland (2003) postulation that genre approach is more suitable for learners at beginning or intermediate levels of proficiency in a second language rather than those at advanced levels, in that it releases students from deep anxieties about their writing tasks. On the other hand, the teachers failure to expound on the mistakes in CW could imply her inadequate knowledge of the same; a limitation that can be eliminated through appropriate ulilisation of genre approach. The next item the teacher handled was creativity which she referred to as 'flavouring' of the composition. In this case, she partially mentioned the use of idiomatic expressions and proverbs. The others aspects of creativity she mentioned were the metaphors and hyperbole and which looked complex to the learner, the learners purpose which takes care of their needs and interests was not put into consideration. This is in line with Johns (2008) assertion that although the writer's purpose is said to be at the centre of the genre theory, 'purposeful' text which is responsive to the students' needs and interests are in reality seldom found in the genre-based L2 classroom. She concluded that in many cases, the learners were producing their text merely 'to please their instructors and/or pass the examinations' (Johns, 2008: 239). For example, Flowerdew (2005) observed that the Japanese EFL learners in his course were producing very similar discourses with little originality and were focusing too much on the correctness of language rather than on generating ideas. Johns (2008) argued that such pedagogy could have limitations in promoting rhetorical flexibility in a given genre and may not be able to prepare students 'for unpredictability of situation that require a reformation of genre schemas' (Johns, 2008: 246).

Over time the realisation of the limitations and possible negative ramifications in the genre-based compounded by the teachers ineffectiveness in the use of this approach approach have led to the attitude that application of this approach alone may not be sufficient in developing students writing 'skills' as competent writers (Litinin, 2012). Therefore, due to these attitude towards the genre approach, which were pronounced in the lessons observed, it is desirable to adequately utilise the approach in the Kenyan classroom to enhance performance, innovativion and creative functions in 
CW. Writing skills ought to be developed gradually as stipulated in the Kenyan writing syllabus. This development cannot take place in a vacuum. Relevant pedagogic strategies and appropriate approaches at this level have to guide the learners in developing a grammatically correct, accurate, original and fluent script.

\section{CONCLUSIONS}

On the basis of the findings of the study on the use of genre approach in developing CW skills, it was concluded that: Teachers in Vihiga County ineffectively used genre approach to teach composition due to inadequate knowledge in $\mathrm{CW}$ approaches, and little attention given to $\mathrm{CW}$ during both pre-service and in-service training. It can be concluded therefore that with the effective use of genre approach to develop aspects of $\mathrm{CW}$, significant improvement can be realized. Appropriate approaches help learners gain confidence during $\mathrm{CW}$ since they know what to write and how to write. Teachers in upper primary school should therefore be encouraged to use genre and approach to improve the teaching of composition because it enhance creativity of thought and language use, accuracy in grammar and fluency in logic and flow of ideas which are key areas in CW. In addition, learners develop an exploratory, investigative and intuitive mind at an early age in the education ladder having gained confidence in writing skills.

\section{RECOMMENDATIONS}

1. Teachers of English should effectively use of product, process and genre approaches in the teaching of composition. This too should be adopted and standardized by the Kenya Institute of Curriculum Development and easily avail to both teachers and learners relevant $\mathrm{CW}$ materials.

2. Teachers should attend regular in-service training and refresher courses on $\mathrm{CW}$ teaching.

\section{REFERENCES}

1. Anderson, N. (2003). Reading. In D. Nunan (Ed.), Practical English Language Teaching (pp. 67-86). New York: McGraw-Hill.

2. Ann, J. M. (2003). Genre in the Classroom: Multiple Perspective.New Jersey: Lawrence Erlbaum Associates Publishers. Cope \& Kalantzis. (1993). Background to Genre Teaching dalam In B. Cope, \& M. Kalantzis (Eds). The Power of Literacy: A Genre Approach to Teaching Christie Frances dan J. R. Martin. (2000). Genre and Institutions: Social Process in the Workplace and School. New York: Continum.

3. Bakhtin, M. (1986). Speech Genres and Other Late Essays. Austin: university of Texas Press.

4. Bruce, I. (2008). Academic Writing and Genre: A Systemic Analysis. British: Continuum.
5. Carter, R. (2004). Language and Creativity: The Art of Common Talk. London: Routledge.

6. Cook, G. (2000). Language Play: Language Learning. Oxford: Oxford University.

7. Craik, F., \& Lockhart R. (1972). Levels of Processing: a Framework for Memory Research. Journal of Verbal Learning and Verbal Behaviour, 11,671-685.

8. Dirgeyasa, Wy. I (2014a). The Development of English Writing Learning Materials through Genre-Based Approach for English Department at University. Proceeding Seminar on English Language and Teaching 2014. English Department, Faculty of Language and Art State University of Padang.

9. Dirgeyasa, Wy. I. (2014b). College Academic Writing: a Genre-based Perspective. Medan: Unimed Press.

10. Dirgeyasa, Wy. I. (2015). What and How to Assess a Genre-Based Writing. Proceeding of 4th International Conference on Language Education. 2015. State University of Makasar South Sulewesi Indonesia.

11. Emilia, E (2011). Pendekatan Genre-based Dalam pengajaran bahasa Inggris: Petunjuka untuk Guru. Bandung: Rizki Press.

12. Emilia, E. (2005). A critical Genre Based Approach to Teaching Academic Writing in a Tertiary EFL Context in Indonesia, PhD thesis, Dept of Language, Literarcy and Arts Education, University of Melbourne.

13. Feez, S. (1998). Text-based Syllabus Design. Sydney: NCELTR-Macquarie University.

14. Fikrins, Arthur Sengupta, Sima, dan Forey, Gail (2007). Teaching Writing to Low Proficiency EFL Students Dalam ELT Journal. Vol. 61/4. Oxford: Oxford University Press. p.p. 343-344

15. Fleith, D. (2000). Teacher and Student Perceptions of Creativity in the Classroom Environment. Education Research Complete.Retrieved on June 19, 2008.

16. Graham, S. (2001). Primary Grade Teachers' Theoretical Orientations Concerning Writing Instruction: Construct Validation and a Nationwide Survey. Contemporary Educational Psychology, 27,147-166.

17. Hyland, K. (2002). Genre: Language, Context, and Literacy. Annual review of applied linguistics, 22, 113-135

18. Hyland, K. (2003). Genre-based Pedagogies: A Social Response to Process. Journal of Second Language Writing, Vol. 12 pp. 17-29.

19. Hyland, K. (2003). Second Language Writing. New York: Cambridge University Press.

20. Hyon, S. (2002). Genre and ESL Reading: A classroom Study. In John, A.M. editor, Genre in the classroom. Mahwah: Lawrence Earlbaum Associates Publishers.

21. John, A.M. (2002). Genre in the Classroom. Mahwah: Lawrence Earlbaum Associates Publishers. 
22. Knapp, P. \& Watkins, M. (2005). Genre, Text, Grammar: Technologies for Teaching and Assessing Writing. Wales: UNSW Press Book.

23. Knapp, P., \& Watkins. (2005). Genre, Text Grammar: Technologies for Teaching and Assessing Writing. Sydney: University of New South Wales Press Ltd. M.A.K.

24. Liddicoat, A,J. et al. (2003). Report on Intercultural Language Learning. Australian Government, Department of Education,

25. Liddicoat, A.J. (2011). Language Teaching and Learning from an Intercultural Perspective. In Hinkel. Handbook of Research in second language teaching and learning. Second edition. Francis: Routledge.

26. Liddicoat, A.J. and Scarina, A. (2013). Intercultural Language Teaching and Learning. Melden: Wiley Blackwell.

27. Martin, J. (2001). Writing Prompts. Jefferson City, MO: Scholastic Professional Books. National Education Association.

28. Martin, J. R. (1999). Factual Writing: Exploring and Challenging Social Reality. Melbourne: Deakin University Press.

29. Muncie, J. (2002). Finding a Place for Grammar in EFL Composition Classes. ELTJournal, 56, 180186.

30. Norman,K.(2005).Our Lives as Writers: Examining Preservice Teachers' Experiences and Beliefs about the Nature of Writing and Writing Instruction. Teacher Education Quarterly, 32(1), 25-40.

31. Paltridge, B. (2001). Genre and the Language Learning Classroom. Ann Arbor, MI: University of Michigan Press.

32. Pardiyono. (2007). Pasti Bisa: Teaching Genre Based Writing. Yogyakarta: Penrbit Andi.

33. Pratista, H. (2007). Memahami Film. Yogyakara: Homerian Pustaka. elt.ccsenet.org English Language Teaching Vol. 9, No. 9; 201651

34. Rezvani, P., Aqdam, S.K, \& Saeidi, M (2008). The Effect of Genre-Based Teaching upon EFL Writing Achievement. Journal of Islamic Azad University, Iran.

35. Santangelo,T. (2008). Using Self-regulated Strategy Development to Support Students who Dave "Trubol giting thangs into werds." Remedial and Special Education, 29(2), 78-87.

36. Science and Training. The university of South Australia. Australia: Commenwealth of Australia.

37. Scott Rebecca dan Avery Simon (eds). (2001). Writing with Style. London: Pearson Education Limited.

38. Seban, D. A. (2008). Look within Individual Cases into Elementary Teachers' Beliefs and Practices of Writing Instruction. Elementary Education, 7(2), 512-521.

39. Simplicio, J. (1999). Teaching Classroom Educators How to be More Effective and Creative Teachers. Education Research Complete. Retrieved on June 19, 2008.
40. Stoke, J. (2006). How to do Media and Cultural Studies Diterjemahkan oleh Santri Indah Astuti (Panduan untuk Melaksanakan Penelitian dalam Kajian Media dan Budaya, Yogyakarta: PT. Benteng Pustaka.

41. Swales, J. M. (1990). Genre Analysis English in Academic and Research Settings: Cambridge: Cambridge University Press.

42. Thoreau, M. (2006). Write on Track. New Zealand: Pearson Education New Zealand.

43. Urquhart, V. (2005). Teaching Writing in the Content Areas. Alexandria, VA: ASCD U.S.

44. Walker, N. (1996). Teaching Writing. Teaching Pre $K-8,26,50-51 . T e a c h e r s$ First (2008). Source for Learning.Retrieved on July 16, 2008, from: http://www.teachersfirst.com/lessons/writers/

45. Weber, J. J. A. (2001). Concordance-and GenreInformed Approach to ESP Essay Writing. ELT Journal, $55(1)$ 15. http://dx.doi.org/10.1093/elt/55.1.14 Copyrights

46. Widdoson, H. G. (2007). Discourse Analysis. Oxford: Oxford University Press.

47. Widodo, H. J. (2006). Designing a Genre-based Lesson Plan for an Academic Writing Course. International Journal of English Teaching: Practice and Critique, Vol.5 No.3. Pages. 173-199.

48. Zimmerman,B.,\&Reisemberg,R. (1997). Becoming a Self-regulated Writer: A Social Cognitive Perspective. Contemporary Education Psychology, 22,73-101. 